\title{
Biogeographic pattern of four endemic Pyropia from the east coast of Korea, including a new species, Pyropia retorta (Bangiaceae, Rhodophyta)
}

\author{
Sun-Mi Kim ${ }^{1}$, Han-Gu Choi ${ }^{1}$, Mi-Sook Hwang ${ }^{2}$ and Hyung-Seop Kim ${ }^{3, *}$ \\ ${ }^{1}$ Division of Polar Life Sciences, Korea Polar Research Institute, Incheon 21990, Korea \\ ${ }^{2}$ Aquatic Plant Variety Center, National Institute of Fisheries Science, Mokpo 58746, Korea \\ ${ }^{3}$ Department of Biology, Gangneung-Wonju National University, Gangneung 25457, Korea
}

Foliose species of the Bangiaceae (Porphyra s. l.) are very important in Korean fisheries, and their taxonomy and ecophysiology have received much attention because of the potential for developing or improving aquaculture techniques. Although 20 species of foliose Bangiales have been listed from the Korean coast, some of them remain uncertain and need further comparative morphological studies with molecular comparison. In this study, we confirm the distribution of four Pyropia species from the east coast of Korea, Pyropia kinositae, P. moriensis, P. onoi, and P. retorta sp. nov., based on morphology and $r b c \mathrm{~L}$ sequence data. Although P. onoi was listed in North Korea in old floral works, its occurrence on the east coast of South Korea is first revealed in this study based on molecular data. P. kinositae and P. moriensis, which were originally described from Hokkaido, Japan, are first reported on the east coast of Korea in this study. Pyropia retorta sp. nov. and P. yezonesis share a similar thallus color and narrow spermatangial patches in the upper portion of the frond, and they have a sympatric distribution. However, $P$. retorta can be distinguished by the curled or twisted thalli and by molecular data. The biogeographic pattern of the two native species, $P$. kinositae and $P$. retorta, suggests that the east coast of Korea may have been a place of refugia during the Last Glacial Maximum (LGM), and then recolonized to the northern part of Japan through the restored East Korean Warm Current after the LGM.

Key Words: biogeography; Last Glacial Maximum; Pyropia kinositae; Pyropia moriensis; Pyropia onoi; Pyropia retorta sp. nov.; $r b c L$ phylogeny; the east coast of Korea

\section{INTRODUCTION}

The foliose Bangiaceae (Engler 1892) is a diverse, cosmopolitan, and distinctive family of morphologically simple red algae that represent an ancient lineage (Butterfield 2000), and economically important seaweeds used as resources in aquaculture for the production of 'gim' or 'nori' in Korea and Japan, respectively (Sutherland et al. 2011, Kim et al. 2017). Identification and systemat- ics within the family, however, have created notorious challenges because of the simple gross morphology with morphological plasticity between individulas. Traditionally, two genera have been recognized in this family, unbranched filamentous thalli assigned to the genus Bangia Lyngbye (1819) and those that are foliose assigned to the genus Porphyra C. Agardh (1824), before the revision
(9) $\$$ This is an Open Access article distributed under the terms of the Creative Commons Attribution Non-Commercial License (http://creativecommons.org/licenses/by-nc/3.0/) which permits unrestricted non-commercial use, distribution, and reproduction in any medium, provided the original work is properly cited.
Received December 19, 2017, Accepted February 26, 2018

* Corresponding Author

E-mail: hskim@gwnu.ac.kr

Tel: +82-33-640-2316, Fax: +82-33-642-6124 
based on a two-gene molecular phylogeny (Sutherland et al. 2011). Currently, Porphyra sensu lato is subdivided into nine genera: Boreophyllum, Clymene, Fuscifolium, Lysithea, Miuraea, Porphyra, Pyropia, Wildemania, and Neothemis (Sutherland et al. 2011, Sánchez et al. 2014, 2015). Revision at the generic level has allowed for a broad understanding of relationships within the family, and the next logical step is to examine species-level taxonomy in detail (Kucera and Saunders 2012, Lindstrom et al. 2015a, 2015b, Guillemin et al. 2016).

Species delineation within foliose Bangiaceae based on morphological analysis alone has proven to be mostly unreliable as it is in many cases for other algal groups (Kucera and Saunders 2012, Sánchez et al. 2014, Verbruggen 2014, Guillemin et al. 2016): combined morphology and molecular studies are needed. For example, approximately $46 \%$ of the foliose specimens (58 out of 126) used in the two gene phylogeny study of Sutherland et al. (2011) were undescribed or with uncertain species identification. Therefore, following extensive studies have focused on the discovery of cryptic new species and correctly identifying local specimens with the application of molecular techniques (e.g., Mateo-Cid et al. 2012, Mols-Mortensen et al. 2012, Nelson 2013, Nelson and D’Archino 2014, Ramírez et al. 2014, Sánchez et al. 2014, Harden et al. 2015, Lindstrom et al. 2015a, 2015b). As a result, 18 species of Pyropia have been newly described among the currently accepted 70 species (excluding 4 infraspecific) names after revision by Sutherland et al. (2011) (see Guiry and Guiry 2017).

Studies have employed a variety of molecular markers for the taxa of Bangiaceae including: SSU-rDNA (e.g., Stiller and Waaland 1993, Kunimoto et al. 1999, Teasdale et al. 2009), rbcL (e.g., Lindstrom and Fredericq 2003, Lindstrom 2008, Kucera and Saunders 2012, MolsMortensen et al. 2012, 2014, Xie et al. 2015), COI-5P (e.g., Kucera and Saunders 2012, Milstein et al. 2012, Xie et al. 2015, Guillemin et al. 2016, Dumilag and Monotilla 2017), and SSU-rDNA + rbcL (e.g., Broom et al. 2010, Sutherland et al. 2011, Mateo-Cid et al. 2012, Sánchez et al. 2014, López-Vivas et al. 2015, Milstein et al. 2015). It was estimated that the mutation rates in mitochondrial DNA causing silent-site divergence between the closely related species Porphyra purpurea and P. umbilicalis were three times faster than that of their plastid DNA and five times that of their nuclear DNA (Smith et al. 2012). Thus, the mitochondrial COI-5P marker is more effective for distinguishing the closely related species of foliose Bangiaceae. The chloroplast $r b c \mathrm{~L}$ gene, however, has been used more widely to assess species diversity of Bangiaceae, and there are more available reference sequences that have been registered in GenBank at present. Therefore, we selected the $r b c \mathrm{~L}$ gene to assess the Korean representatives in this study.

The foliose Bangiaceae of Korean representatives were revised based on characteristics of morphology and distribution (Hwang and Lee 2001, Kim and Kim 2011), and up 20 foliose species were listed, including two uncertain records and one forma (Kim et al. 2013). Although Korean specimens of six species of Pyropia and one unidentified Wildemania were included in the two-gene molecular phylogeny (Sutherland et al. 2011), most have yet to by their distributional range and morphology. In our preparatory molecular work of Korean foliose Bangiaceae after a monographic study (Kim and Kim 2011), several unreported or cryptic species were found. Most of them are restricted to the east coast of Korea and northern Japan based on $r b c \mathrm{~L}$ sequences data (unpublished). In this research, we present analyses of four targeted native species along the coast of Korea, P. kinositae (Yamada \& Tak. Tanaka) N. Kikuchi, M. Miyata, M. S. Hwang \& H. G. Choi, P. onoi (Ueda) N. Kikuchi \& M. Miyata, P. moriensis (Ohmi) N. Kikuchi \& M. Miyata, and P. retorta sp. nov., and we discuss the distributional characteristics as a possible result of Quaternary climatic oscillations of the East Sea (= Sea of Japan).

\section{MATERALS AND METHODS}

\section{Collections}

Specimens were collected as gametophytes on the coast of South Korea from 2004 to 2013 (Table. 1). The collected fresh field material was transferred to the laboratory in a cooler, and several distinctive types were sorted to be pressed as voucher specimens. A small portion (ca. $1.5 \times 1.5 \mathrm{~cm}$ ) near the center of a voucher specimen was removed for DNA analysis. The small portion was cleaned by removing attached diatoms or small tiny filamentous algae using a small brush or with fine forceps under a dissecting microscope; it was then rinsed several times with fresh distilled water. The clean fragments of each voucher were dried at $50^{\circ} \mathrm{C}$ and stored in silica gel to preserve DNA. All vouchers used in this study were deposited at the herbarium of the Gangneung-Wonju National University. 


\section{Morphology}

Morphological and anatomical observations were conducted with sexually mature fresh thalli or on partially rehydrated fragments of the vouchers using $4 \%$ formalin-seawater. Transverse sections were made us- ing a CM1850 cryostat (Leica Microsystems, Heidelberg, Germany), but cutting sections by hand with a stainlesssteel razor blade was more practical in many cases. Photomicrographs were taken with an Olympus DP70 digital camera coupled to an Olympus BX50 light microscope (Olympus, Tokyo, Japan).

Table 1. Collection information and GenBank accession numbers for Pyropia kinositae, P. moriensis, P. onoi, and P. retorta

\begin{tabular}{|c|c|c|c|c|}
\hline Species & Strain & Collection information & $r b c \mathrm{~L}$ & SSU-rDNA \\
\hline \multirow[t]{8}{*}{ Pyropia kinositae } & IK153 & $\begin{array}{l}\text { Ingu, Yangyang, Gangwon-do, Korea } \\
\left(37^{\circ} 56^{\prime} 42.82^{\prime \prime} N, 128^{\circ} 47^{\prime} 13.48^{\prime \prime} \text { E; Mar 14, 2004) }\right.\end{array}$ & MG926655 & MG926677 \\
\hline & IK158 & $\begin{array}{l}\text { Gyoam, Goseong, Gangwon-do, Korea } \\
\left(38^{\circ} 17^{\prime} 25.23^{\prime \prime} \text { N, } 128^{\circ} 32^{\prime} 43.89^{\prime \prime} \text { E; Jun } 4,2004\right)\end{array}$ & MG926656 & MG926678 \\
\hline & IK327 & $\begin{array}{l}\text { Daejin, Goseong, Gangwon-do, Korea } \\
\left(38^{\circ} 30^{\prime} 15.06^{\prime \prime} \mathrm{N}, 128^{\circ} 25^{\prime} 45.87^{\prime \prime} \mathrm{E} \text {; Mar } 3,2005\right)\end{array}$ & MG926657 & - \\
\hline & IK328 & $\begin{array}{l}\text { Gyeongpo, Gangneung, Gangwon-do, Korea } \\
\left(37^{\circ} 48^{\prime} 36.58^{\prime \prime} \text { N, } 128^{\circ} 54^{\prime} 45.87^{\prime \prime} \text { E; Mar 4, 2005) }\right.\end{array}$ & MG926658 & - \\
\hline & IK330 & $\begin{array}{l}\text { Hosan, Samcheok, Gangwon-do, Korea } \\
\left(37^{\circ} 11^{\prime} 46.74^{\prime \prime} \text { N, } 129^{\circ} 20^{\prime} 34.29^{\prime \prime} \text { E; Mar 5, 2005) }\right.\end{array}$ & MG926659 & - \\
\hline & IK331 & $\begin{array}{l}\text { Heunghwan, Pohang, Gyeongbuk, Korea } \\
\left(36^{\circ} 08^{\prime} 24.19^{\prime \prime} \text { N, } 129^{\circ} 23^{\prime} 48.08^{\prime \prime} \text { E; Mar 5, 2005) }\right.\end{array}$ & MG926660 & - \\
\hline & KU366 & $\begin{array}{l}\text { Punghwa, Tongyeong, Gyeongnam, Korea } \\
\left(34^{\circ} 49^{\prime} 47.16^{\prime \prime} \mathrm{N}, 128^{\circ} 22^{\prime} 19.92^{\prime \prime} \mathrm{E} \text {; Feb 28, 2010) }\right.\end{array}$ & MG926661 & - \\
\hline & KIN301 & $\begin{array}{l}\text { Yeonam, Pohang, Gyeongbuk, Korea } \\
\left(36^{\circ} 07^{\prime} 44.943^{\prime \prime} \mathrm{N}, 129^{\circ} 41^{\prime} 85.37^{\prime \prime} \mathrm{E} \text {; Mar 1, 2002) }\right.\end{array}$ & MG926662 & - \\
\hline Pyropia morriensis & KU408 & $\begin{array}{l}\text { Hwajinpo, Goseong, Gangwon-do, Korea } \\
\left(38^{\circ} 19^{\prime} 38.35^{\prime \prime} \text { N, } 128^{\circ} 25^{\prime} 45.63^{\prime \prime} \text { E; Mar 9, 2010) }\right.\end{array}$ & MG926663 & MG926679 \\
\hline Pyropia onoi & KU407 & $\begin{array}{l}\text { Hwajinpo, Goseong, Gangwon-do, Korea } \\
\left(38^{\circ} 19^{\prime} 38.35^{\prime \prime} \text { N, } 128^{\circ} 25^{\prime} 45.63^{\prime \prime} \text { E; Mar 9, 2010) }\right.\end{array}$ & MG926664 & MG926680 \\
\hline \multirow[t]{12}{*}{ Pyropia retorta sp. nov. } & IK111 & $\begin{array}{l}\text { Sacheon, Gangneung, Gangwon-do, Korea } \\
\left(37^{\circ} 50^{\prime} 21.43^{\prime \prime} \mathrm{N}, 128^{\circ} 52^{\prime} 39.42^{\prime \prime} \text { E; Dec } 16,2003\right)\end{array}$ & MG926665 & MG926681 \\
\hline & SM018 & $\begin{array}{l}\text { Jumunjin, Gangneung, Gangwon-do, Korea } \\
\left(37^{\circ} 54^{\prime} 21.80^{\prime \prime} \text { N, } 128^{\circ} 49^{\prime} 49.77^{\prime \prime} \text { E; Mar 20, 2004) }\right.\end{array}$ & MG926666 & MG926682 \\
\hline & KN033 & $\begin{array}{l}\text { Hosan, Samcheok, Gangwon-do, Korea } \\
\left(37^{\circ} 10^{\prime} 23.80^{\prime \prime} \text { N, } 129^{\circ} 20^{\prime} 44.20^{\prime \prime} \text { E; Jan } 24,2006\right)\end{array}$ & MG926667 & - \\
\hline & KU652 & $\begin{array}{l}\text { Ingu, Yangyang, Gangwon-do, Korea } \\
\left(37^{\circ} 58^{\prime} 33.20^{\prime \prime} \mathrm{N}, 128^{\circ} 45^{\prime} 44.90^{\prime \prime} \mathrm{E} \text {; Feb } 25,2010\right)\end{array}$ & MG926668 & - \\
\hline & KU654 & $\begin{array}{l}\text { Chodo Harbour, Goseong, Gangwon-do, Korea } \\
\left(38^{\circ} 28^{\prime} 56.87^{\prime \prime} \text { N, } 128^{\circ} 26^{\prime} 18.97^{\prime \prime} \text { E; Mar 30, 2010) }\right.\end{array}$ & MG926669 & - \\
\hline & KU655 & $\begin{array}{l}\text { Yeongjin, Gangneung, Gangwon-do, Korea } \\
\left(37^{\circ} 54^{\prime} 21.80^{\prime \prime} \text { N, } 128^{\circ} 49^{\prime} 49.77^{\prime \prime} \text { E; Mar } 25,2010\right)\end{array}$ & MG926670 & - \\
\hline & KU656 & $\begin{array}{l}\text { Namae, Yangyang, Gangwon-do, Korea } \\
\left(37^{\circ} 56^{\prime} 35.91^{\prime \prime} \mathrm{N}, 128^{\circ} 47^{\prime} 20.00^{\prime \prime} \text { E; Mar 18, 2010) }\right.\end{array}$ & MG926671 & - \\
\hline & KU668 & $\begin{array}{l}\text { Guryongpo, Pohang, Gyeongbuk, Korea } \\
\left(35^{\circ} 59^{\prime} 23.10^{\prime \prime} \mathrm{N}, 129^{\circ} 34^{\prime} 08.00^{\prime \prime} \mathrm{E} \text {; Mar 18, 2010) }\right.\end{array}$ & MG926672 & - \\
\hline & KU757 & $\begin{array}{l}\text { Jumunjin, Gangneung, Gangwon-do, Korea } \\
\left(37^{\circ} 54^{\prime} 21.80^{\prime \prime} \text { N, } 128^{\circ} 49^{\prime} 49.77^{\prime \prime} \text { E; Mar 12, 2011) }\right.\end{array}$ & MG926673 & - \\
\hline & KU758 & $\begin{array}{l}\text { Jumunjin, Gangneung, Gangwon-do, Korea } \\
\left(37^{\circ} 54^{\prime} 21.80^{\prime \prime} \text { N, } 128^{\circ} 49^{\prime} 49.77^{\prime \prime} \text { E; Mar 12, 2011) }\right.\end{array}$ & MG926674 & - \\
\hline & KW020 & $\begin{array}{l}\text { Anin, Gangneung, Gangwon-do, Korea } \\
\left(37^{\circ} 44^{\prime} 02.96^{\prime \prime} \mathrm{N}, 128^{\circ} 59^{\prime} 26.14^{\prime \prime} \mathrm{E} \text {; Mar 18, 2011) }\right.\end{array}$ & MG926675 & - \\
\hline & KW568 & $\begin{array}{l}\text { Ingu, Yangyang, Gangwon-do, Korea } \\
\left(37^{\circ} 58^{\prime} 50.28^{\prime \prime} \mathrm{N}, 128^{\circ} 45^{\prime} 46.17^{\prime \prime} \mathrm{E} \text {; Mar 18, 2017) }\right.\end{array}$ & MG926676 & - \\
\hline
\end{tabular}




\section{DNA extraction and polymerase chain reaction}

DNA samples were extracted using the i-genomic Plant DNA Extraction Kit (iNtRON Biotechnology, Seongnam, Korea) following the manufacturer's instructions. Polymerase chain reaction (PCR) was performed using specific primers for each gene with Takara Ex Taq (Takara Bio Inc., Otsu, Japan) and Quick Taq HS DyeMix (Toyobo, Osaka, Japan). All the reactions were performed in 50 $\mu \mathrm{L}$ volumes containing $5 \mu \mathrm{L} 10 \times$ Ex Taq buffer, $4 \mu \mathrm{L} 2.5$ $\mathrm{mM}$ each dNTP, $4 \mu \mathrm{L}$ each of the appropriate primers at $10 \mathrm{pM}$, and 0.3-0.5 $\mu \mathrm{L}$ Taq DNA polymerase (Takara Ex Taq). PCR cycle and amplification were performed with SSU-rDNA primer pairs (G01/G14, G04/G07) (Saunders and Kraft 1994) and the $r b c L$ primer pairs (FrbcL/R1150, F753 or F993+/RrbcSp) (Freshwater and Rueness 1994, Bárbara et al. 2013). PCR products were purified with the QIAquick PCR Purification Kit (Qiagen Inc., Valencia, CA, USA) or the MG PCR Product Purification Kit (Microgen, Seoul, Korea) following the manufacturer's recommendations for direct sequencing. Sequencing reactions were performed with the BigDye Terminator Cycle Sequencing Kit (Macrogen, Seoul, Korea), and samples were loaded in an ABI 3730 DNA Genetic Analyzer (Applied Biosystems, Foster City, CA, USA). Sequence reads were manually assembled and edited in BioEdit ver. 7.0.5 (Hall 1999), and chromatograms were checked to confirm the validity of ambiguous nucleotides.

\section{Phylogenetic analysis}

A dataset consisting of 104 rbcL sequences (including our six newly determined sequences [MG926655MG926676] and three outgroups were trimmed to the same length of $1,313 \mathrm{bp}$ ) and were used to evaluate the phylogenetic position of our newly acquired Pyropia species. We selected one sequence from each currently listed species of Pyropia and putative cryptic taxa from GenBank (Supplementary Table S1) (Guiry and Guiry 2017) to provide broader a distributional pattern for the Pyropia genetic group as possible. However, short $r b c \mathrm{~L}$ sequences (ca. 870 bp) of putative cryptic species of Pyropia from Chile (López-Vivas et al. 2015, Guillemin et al. 2016) were discarded prior to the final analysis. In addition, five species and one variety, which are currently listed taxa in AlgaeBase (Guiry and Guiry 2017) were excluded because of the lack of available sequence data (e.g., P. drachii) or short $r b c \mathrm{~L}$ sequences (P. orbicularis, $P$. raulaguilarii). The registered $r b c \mathrm{~L}$ sequences of $P$. pulchella (Ackland, J. A. West, J. L. Scott \& Zuccarello) T. J. Farr \& J. E. Sutherland,
P. stamfordensis C. Neefus, T. Bray \& A. C. Mathieson (as named Porphyra sp. stamfordensis), and P. collinsii C. Neefus, T. Bray et A. C. Mathieson (as named Porphyra sp. collinsii) in GenBank were also excluded because the sequence of $P$. pulchella the same of $P$. kuniedae, and $P$. stamfordensis and P. collinsii the same of $P$. parva (see Supplementary Table S1).

Appropriate models of sequence evolution were assessed using jModelTest 2 (Darriba et al. 2012) under both AIG criteria. Model selection occurred with the following parameters: GTR + I + G with gamma distribution $=1.4330$; proportion of invariable sites $=0.6340$; base frequencies $\mathrm{A}=0.3222, \mathrm{C}=0.1460, \mathrm{G}=0.1698, \mathrm{~T}=0.3620$; and rate among sites $[\mathrm{A}-\mathrm{C}]=0.7479,[\mathrm{~A}-\mathrm{G}]=5.7755,[\mathrm{~A}-\mathrm{T}]=$ 0.5708, $[\mathrm{C}-\mathrm{G}]=0.4281,[\mathrm{C}-\mathrm{T}]=8.8906$, and $[\mathrm{G}-\mathrm{T}]=1.0000$. Maximum likelihood analyses were conducted using PhyML ver. 3.0 (Guindon et al. 2010), under the appropriate model of sequence evolution, and with support both calculated by an approximate likelihood ratio test (aLRT) (Anisimova and Gascuel 2006) and by a bootstrap analysis using 1,000 pseudoreplicates. Bayesian inference was implemented in MrBayes ver. 3.1.2 (Huelsenbeck and Ronquist 2001). Two independent analyses were run with four chains of the Markov chain Monte Carlo (one hot and three cold), sampling one tree every 100 generations for 1,000,000 generations, starting with a random tree. A total of 30,000 generations were discarded as "burn in." p-Distance analyses were calculated for the phylogenetic matrix in MEGA ver. 5.05 (Tamura et al. 2011).

\section{RESULTS}

\section{Molecular analysis}

In our reconstructed maximum likelihood (ML) phylogram ( $\ln \mathrm{L}=12,761.2691)$ (Fig. 1), the species of the genus Pyropia formed a well-supported monophyletic taxon, as in previously published trees of $r b c \mathrm{~L}$ (Kucera and Saunders 2012) or concatenated rbcL-rSSU trees (Sutherland et al. 2011, Meteo-Cid et al. 2012, Sánchez et al. 2014). Topologies of our data were similar with previously reconstructed trees (Fig. 1), but slightly differed from those of ML and Bayesian trees by the position of P. garderni, which was nested as sister of Clade V in Bayesian analysis (data not shown). Our rbcL ML tree was resolved with five moderately supported clades: 1) $P$. onoi clade; 2) $P$. gardneri clade; 3) Clade III [supporting values (sv): ML bootstrap / Bayesian posterior probability / aLRT value (sv: -/0.87/0.83)]; 4) Clade IV (sv: -/0.78/0.80); and 5) 


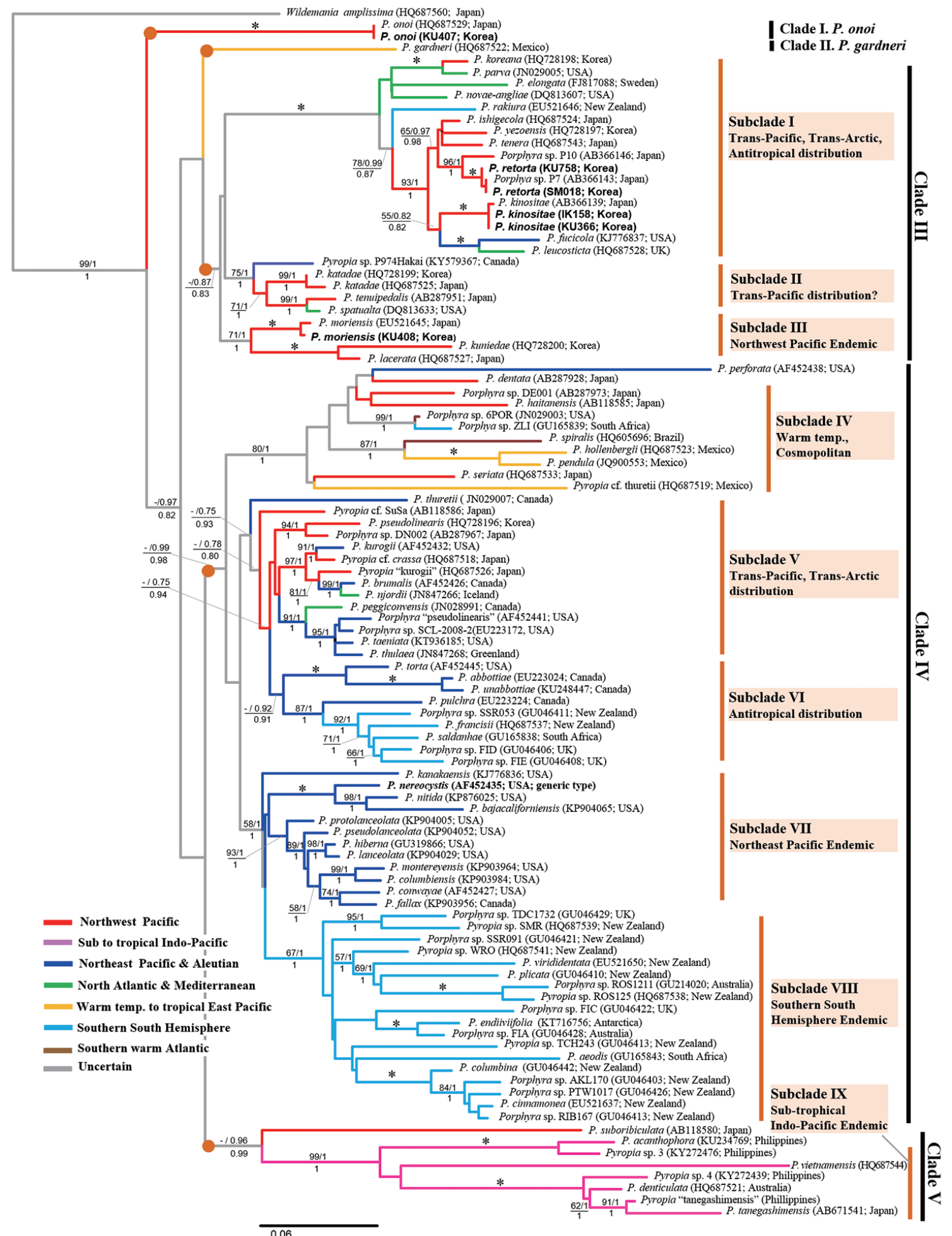

Fig. 1. A maximum likelihood (ML) phylogram of the genus Pyropia based on rbcL sequences combined with information on geographical distribution, showing regional endemic, Trans-Arctic and / or Trans-equatorial lineages. ML bootstrap (BS) / Bayesian posterior probability (PP) values are shown above each branch, and approximate likelihood ratio test (aLRT) supporting values below. Branches that received full support $(100 / 1 / 1)$ are marked with an asterisk. Only supporting values higher than 50\% (BS), 0.75 (PP), and 0.75 (aLRT) are shown, and these are only shown on branches for which two support values exceeded these cutoffs. New sequence data from this study are shown in bold and the name of the clade and subclade are defined arbitrarily in this study. The outgroup species, Boreophyllum aestivale and Bangia gloiopeltidicola, were excised from the printed tree. 
Clade V (sv: - /0.96/0.99). The early separated clade corresponding to $P$. onoi was similar to that of previous reports (Sutherland et al. 2011, Sánchez et al. 2014). Each clade had a tendency for a biogeographic pattern; these five clades are divided into approximatively nine subclades based on clustering and distribution (Fig. 1).

Interestingly, the putative endemic species of the Northwest Pacific were scattered subclades in I, VI, and $\mathrm{V}$, and mixed with the Northeast Pacific or Arctic to North Atlantic species. Moreover, strong sibling relationships between the Northwest Pacific and the Northeast Pacific species or between the Northeast Pacific and Arctic or North Atlantic species (e.g., P. kinositae-P. fucicola-P. leucosticta and P. kurogii-P. brumalis-P. njordii) were convincing evidence of a link between species diversification of Pyropia and the Trans-Pacific to Trans-Arctic expansion histories from the Northwest Pacific members. Our phylogenetic tree also showed evidence of anti-tropical distribution relationships between the Northwest Pacific and the southern hemisphere species in subclades I and VI and between subclades VII and VIII. On the other hand, four strict biogeographic endemic clades were resolved: in the Northwest Pacific (subclade III), in the Northeast Pacific (subclade VII), in the southern South hemisphere (subclade VIII), and in the Indo-Pacific waters (subclade IX).

\section{Delineation of species based on $r b c L$ sequence data}

Our 24 newly determined complete $r b c \mathrm{~L}$ sequences from Korean specimens (Table 1) identified four species, $P$. kinositae, $P$. moriensis, $P$. onoi, and a cryptic species (KU758 and SM018) (Fig. 1). Twenty-four sets of sequence data among them were nested in the subclade I at two terminal branches (Fig. 1). The subclade was well resolved as a strongly supported monophyletic clade, which was composed of 13 taxa at the species level, including two of the most economically important species for aquaculture, P. yezoensis (Ueda) M. S. Hwang \& H. G. Choi and P. tenera (Kjellman) N. Kikuchi, M. Miyata, M. S. Hwang \& H. G. Choi (Fig. 1). One type of $r b c \mathrm{~L}$ sequence (8 out of 24) in our data was identified as P. kinositae (Yamada \& Tak. Tanaka) N. Kikuchi, M. Miyata, M. S. Hwang \& H. G. Choi, which had previously only been reported in Northern Japan (Hokkaido and the northeast coast of Honshu) based on the literature and GenBank data, and another type of $r b c L$ sequence (14 out of 24) was identical with those of Porphyra "P7" (GenBank accession No. AB366143). The other two rbcL sequences (KU407 and
KU408) were nested in Japanese P. onoi (Ueda) N. Kikuchi \& M. Miyata and P. moriensis (Ohmi) N. Kikuchi \& M. Miyata, respectively.

\section{Taxonomic treatment}

Pyropia retorta sp. nov. S. -M. Kim, H. -G. Choi \& H. -S. Kim.

Description. Thalli membranous, monostromatic, color darkish red in the upper portion and greenish red in lower the portion, axially curled or twisted, shape lanceolate to oblanceolate with obtuse to rotund base without conspicuous stipe (Fig. 2A-C), 6-15 (-35) cm long, 0.8-3 $(-8) \mathrm{cm}$ broad, and $35-42 \mu \mathrm{m}$ thick in the central vegetative portion. Margins entire, slightly undulated (Fig. 2D). Each cell contains a single stellate plastid with central pyrenoid. Vegetative cells oblong or irregular tetragonal to polygonal with rounded angles, and 15-25 $\mu \mathrm{m}$ long $\times$ 8-15 $\mu \mathrm{m}$ broad in surface view, and oblong and quadrate with round angles, $20-23 \mu \mathrm{m}$ high $\times 8-15 \mu \mathrm{m}$ broad in sectional view (Fig. $2 \mathrm{~F} \& \mathrm{G}$ ). Basal cells capitate with projected rhizoidal filaments, $15-40 \mu \mathrm{m}$ long $\times 10-15 \mu \mathrm{m}$ broad in surface view. Rhizoidal filaments arranged in both directions in sectional view. Thalli mixed monoecious. Spermatangia in longitudinal linear patches with a sharp boundary, formed and arranged in parallel with zygotosporangial patches distally and along margins, each containing $128(\mathrm{a} / 4, \mathrm{~b} / 4, \mathrm{c} / 8)$ at maximum (Fig. 2C, J \& K). Prototrichogyne conspicuous, acute to obtuse (Fig. 2H). Zygotosporangia containing $16(\mathrm{a} / 2, \mathrm{~b} / 2, \mathrm{c} / 4)$ at maximum (Fig. 2I \& J). Thalli 47-50 $\mu \mathrm{m}$ thick in spermatangial portion, 58-62 $\mu \mathrm{m}$ in zygotosporangial portion.

Holotype. Gametophyte NIBRRD0000003217 (SM018) collected on Mar 20, 2004 in Jumunjin, Gangneung (Gangwon-do, Korea; 375' $21.80^{\prime \prime}$ N, 128 $49^{\prime} 49.77^{\prime \prime}$ E) by S. M. Kim and deposited in the National Institute of Biological Resources (NIBR), Incheon, Korea.

Isotype. NIBRRD0000003218 (SM018-1) deposited in the NIBR, Incheon, Korea.

Etymology. The specific epithet refers to the curled or axially twisted nature of the thallus.

Representative specimens examined. IK111, KN033, KU652, KU654, KU655, KU656, KU668, KU757, KU758, KW020, and SM018 deposited in the Herbarium of Gangneung National University (Table 1).

Habitat and geographical distribution. Blade phase is epilithic, inhabiting exposed intertidal areas, where splashed intermittently by waves. This phase is a seasonal annual, occurring from January to April, and it can form dense populations solely or intermixed with P. pseudolin- 

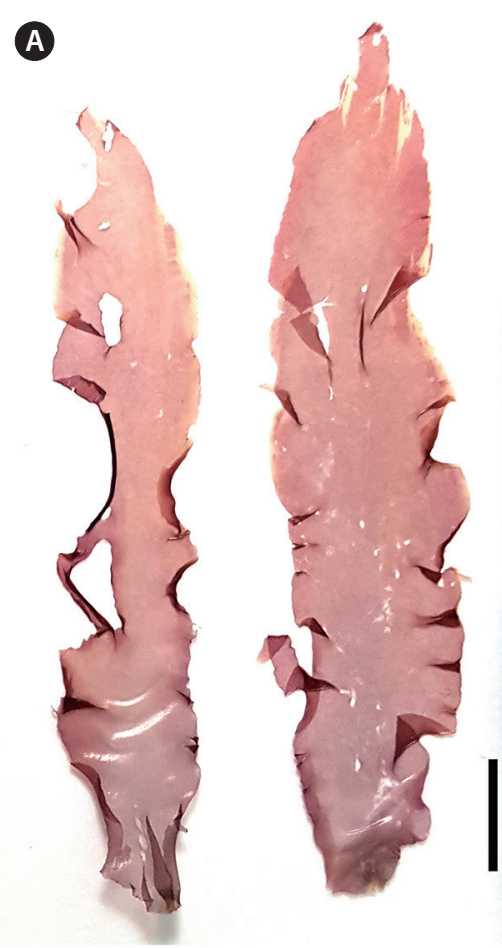

B
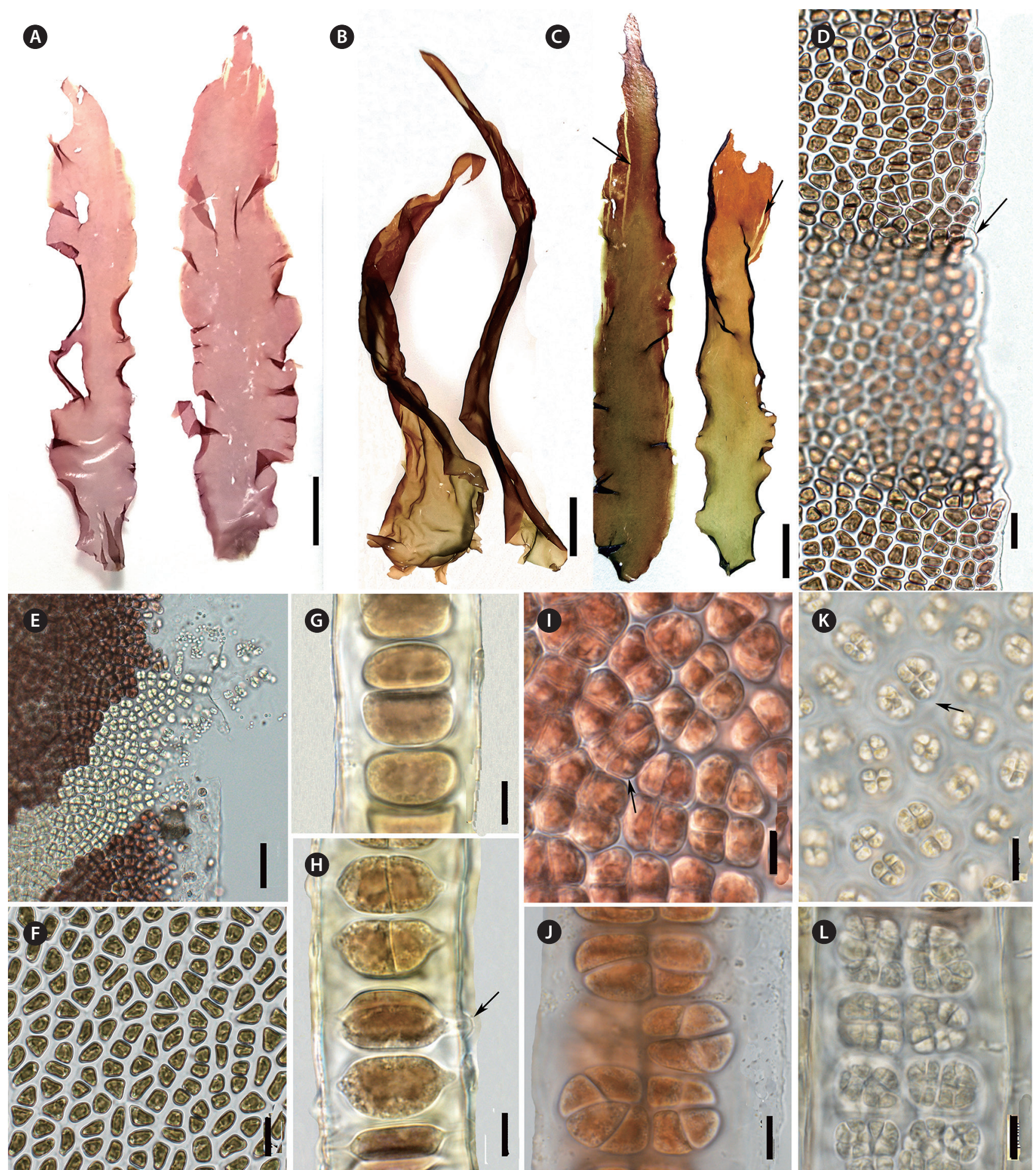

(H)
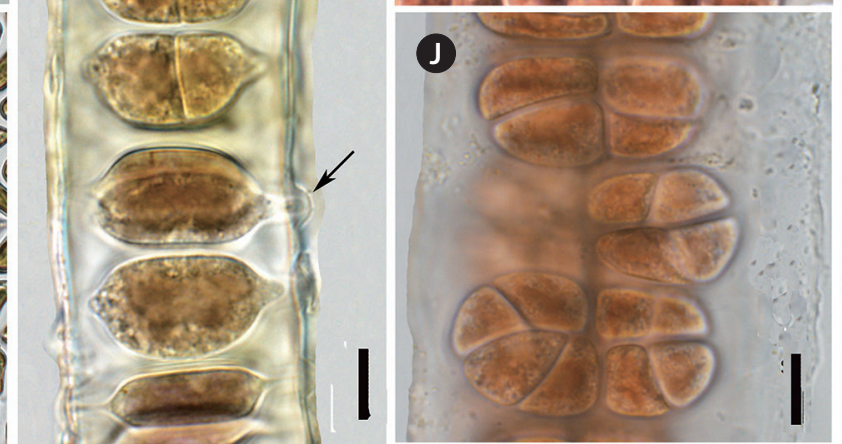

Fig. 2. Vegetative and reproductive structure of the gametophytes of Pyropia retrota S. -M. Kim, H. G. Choi et H. -S. Kim sp. nov. (A) Holotype herbarium specimen. (B) Living specimens, showing heavily curled and twisted thalli (KW568). (C) Herbarium specimen (KW568) retained almost its original color, showing a greenish red color in the lower portion and very narrow spermatangial patches in the upper portion of the frond (arrows). (D) Vegetative cells and smooth margin in the surface view of the lower portion of the frond, showing undulation (arrow). (E) Surface view of mixed spematangia and zygosporangia. (F) Surface view of vegetative cells in middle-upper central portion. (G) Vegetative cells in the cross-section of the middle portion. (H) Carpogonia with protruding prototrichogynes in the cross-section (arrow). (I) Surface view of zygotosporangial patches (arrow). (J) Mature zygotosporangia in the cross-section. (K) Surface view of spermatangial patches (arrow). (L) Mature spermatangia in the cross-section. Scale bars represent, A-C, $1 \mathrm{~cm} ; \mathrm{D} \& \mathrm{~F}, 20 \mu \mathrm{m} ; \mathrm{E}, 50 \mu \mathrm{m} ; \mathrm{G}-\mathrm{L}, 10 \mu \mathrm{m}$. 
earis (Ueda) N. Kikuchi, M. Miyata, M. S. Hwang \& H. G. Choi. To estimate the distribution range based on GenBank data and our molecular work, this species is only known in the Northwest Pacific, as an endemic, from the east coast of Korea to Northern Japan (Hokkaido, northern east coast of Honshu) (see Fig. 3).

Molecular sequences of type material. $r b c \mathrm{~L}$ GenBank (MG926666); nSSU-rDNA GenBank (MG926682).

Morphology. The thalli are heavily twisted or axially curled in nature, and thus very difficult to spread on herbarium sheets to make dry specimens (Fig. 2B). Thalli are darkish red in the upper part and greenish red in the lower part when fresh (Fig. 2B \& C), and darkish brown with a yellowish green basal portion when pressed and dried at first (Fig. 2A \& B), but the greenish color gradually fades as time goes in herbarium specimens (Fig. 2A). Specimens adhere moderately well to paper. This species is always monoecious with conspicuous linear and narrow (400-550 $\mu \mathrm{m}$ broad) spermatangial patches, which are almost parallel to the axis and penetrated by broaden darkish red zygotosporangial areas of the upper blade margins (Fig. 2C). Archeospores (monospores) were not observed, at least in wild plants.

\section{DISCUSSION}

\section{Taxonomic perspective}

Pyropia is the most speciose genus among bladed Bangiaceae, and has a wide geographic distribution around the world, from tropical to subpolar waters (Sutherland et al. 2011). Although 70 species names are currently accepted taxonomically in the genus Pyropia (Guiry and Guiry 2017), three species among them were not resolved as distinct species in our $r b c \mathrm{~L}$ phylogenetic analysis. $P y$ ropia collinsii Neefus, T. Bray \& A. C. Mathieson should be treated as a heterotypic synonym of Pyropia parva A. Vergés \& N. Sánchez based on identical $r b c \mathrm{~L}$ sequence data between both species (see Sánchez et al. 2014). On the other hand, P. pulchella (Ackland, J.W.West, J. L. Scott \& Zuccarello) T. J. Farr \& J. E. Sutherland and P. stamfordensis Neefus, T. Bray \& A. C. Mathieson should be treated as heterotypic synonyms of P. kuniedae (Kurogi) M. S. Hwang \& H. G. Choi based on identical $r b c \mathrm{~L}$ sequences among them.

The occurrence of $P$. onoi is confirmed based on molecular data in Korea after being reported from the northern part of the east coast of North Korea (Ueda 1932). The specimens were collected only once during this study as epiphytes on Grateloupia asiatica S. Kawaguchi \& H. W. Wang. In the field, the epiphytic character of this species attracted our attention even though its gross morphology is similar to epilithic P. suborbiculata (Porphyra okamurae sensu Ueda), which is abundant at the collection site. Under microscopic observations, the specimens of the former are clearly distinguished from the latter by the entire margin of thallus, monoecious thalli with narrow spermatangial streaks around the margin, and absence of monospore production (Supplementary Fig. S1). P. onoi has been known as an epiphyte on Mazzaella japonica (Mikami) Hommersand and Chondrus yendoi Yamada \& Mikami (Ueda 1932). Based on the $r b c \mathrm{~L}$ sequence data, the Korean specimen has the same haplotype as that reported from Hokkaido, Japan (HQ687529).

Also, the distribution of P. moriensis on the east coast of Korea was confirmed for the first time in this study. However, we could collect only one specimen, which was cast ashore, in spite of several attempts and much attention to obtain more material. The specimen was mixed with numerous cast ashore thalli of $P$. kinositae, but it was distinguished from the latter by its pale reddish color and absence of longitudinal linear spermatangial patches (Supplementary Fig. S2). This species has been known as an obligate epiphyte on Chorda filum (Linnaeus) Stackhouse (Ohmi 1954, Notoya and Miyashita 1999); however, the host of the Korean specimen was indeterminable because the cast ashore thallus was detached. C. filum is relatively common on the south and southwest coast, but rare on the east coast of Korea, only collected once when it was cast ashore on the northern east coast (personal observation). The $r b c \mathrm{~L}$ sequences of the Korean and Japanese specimens differed by 2 bp substitutions.

Our $r b c \mathrm{~L}$ data also confirmed the widespread distribution of P. kinositae on the east coast of Korea (Fig. 3B). Most specimens were collected when they were cast ashore from late January to the middle of May on the east coast of Korea, especially in Gangwon-do Province. We could verify the habitat of this species by SCUBA diving collection in shallow to moderately deep subtidal zone (ca. to $20 \mathrm{~m}$ depth) on bare rocks or on coralline algae. The species was described as a forma as Porphyra yezoensis f. kinositai (Tanaka 1952), largely based on its subtidal habitat (3-7 fathoms = ca. 5-15 $\mathrm{m}$ in depth). The darkish purplish red thalli are one of the diagnostic characters distinguishing this species from P. yezoensis, which is greenish in color at least in the lower part of the thallus (Kim and Kim 2011). The other morphological characteristics of the Korean samples agreed well with the descriptions of Tanaka (1952) and Fukuhara (1968) (Supple- 

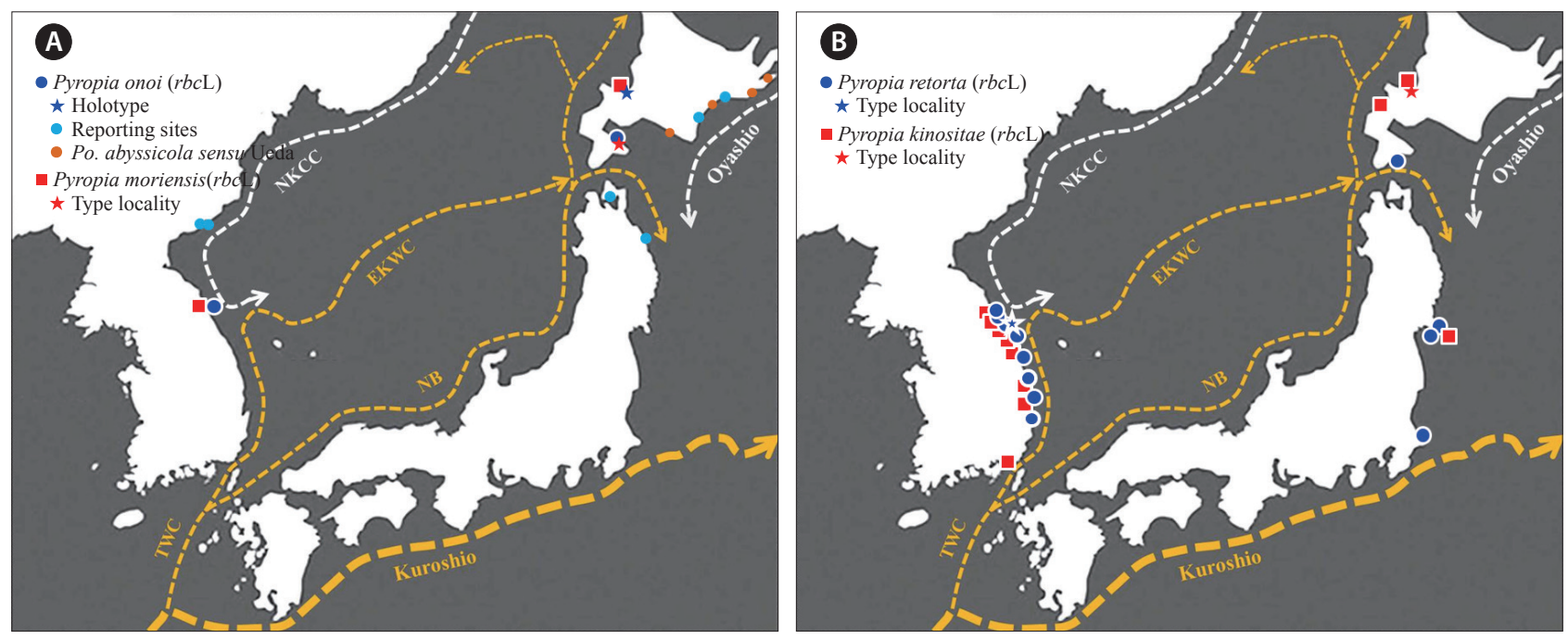

Fig. 3. Distributional maps of Pyropia onoi and P. moriensis (A), P. kinositae and $P$. retorta (B) based on rbcL sequence data, showing the close relation with the East Korea Warm Current (EKWC) at least in the biogeographic patterns of $P$. kinositae and $P$. retorta. TWC, Tsushima Warm Current; NB, Nearshore branch of TWC; NKCC, North Korean Cold Current. The schematic sea currents are modified based on the map published by the Korean Hydrographic and Oceanographic Agency (2016) (http://www.khoa.go.kr/koofs/kor/seawf/sea_wflow.do?menuNo).

mentary Fig. S3). All rbcL sequences of Korean specimens were identical with those of Japan specimens (AB366145, EU521641), except for 1 bp substitution in the Japanese Otaru specimen (AB366139) among the 1,467 bp of the complete $r b c \mathrm{~L}$ sequence. The species has not been recorded on the west coast of Japan to date and is distributed only on the west and southern coasts of Hokkaido and the northern part of Honshu (Fukuhara 1968) (Fig. 3B).

Another epilithic Pyropia sp. was shown to be having a similar biogeographic pattern to that of $P$. kinositae (Fig. 3B). The $r b c \mathrm{~L}$ sequences of 14 Korean specimens were identical or differed by only $1 \mathrm{bp}$ substitution with those of Japanese Porphyra sp. P7 (AB366143). This species is common and usually collected from the lower tide level to the supralittoral zone (ca. $1 \mathrm{~m}$ level up from the hightide level) in the east coast of Korea. The occurrence of this cryptic species was previously recognized in Korea based on molecular data by Kim (2005) and Niwa et al. (2014). Furthermore, Niwa and Kobiyama (2014) verified the interspecific hybridization between Pyropia sp. 2 (= P. retorta) and Pyropia sp. 3 (Pyropia sp. P10 in Fig. 1) as in the case of P. yezoensis and P. tenera (Niwa et al. 2009, Niwa and Sakamoto 2010). This species is clearly distinguished by its unique morphological characteristics and $r b c \mathrm{~L}$ sequences from the closely related species $P$. yezoen$s i s$, and thus we proposed as a new species $P$. retorta in this study.

\section{Biogeographic pattern of the four native Pyropia}

Our newly determined $r b c$ L sequence data can be used to describe the biogeographic patterns of the four native species. The four species are basically restricted to the east coast of Korea and the western to southern part of Hokkaido (and northeastern Honshu) in Japan. The biogeographic pattern of the two species, P. kinositae and $P$. retorta, suggests that they are native to the east coast of Korea, and it seems highly probable that they were isolated and remained in the southern part of East Sea (Sea of Japan) during the Last Glacial Maximum (LGM): the pattern coincides with the East Korean Warm Current (Fig. 3B). Although the distributional data is limited to date, $P$. onoi and P. moriensis show different pattern that relates with North Korean Cold Current because they are not observed in the southern east coast of Korea (Fig. 3A). However, the distribution range of $P$. onoi should be revised based on molecular data including the representatives of Porphyra abyssicola sensu Ueda (1932) in Japan. The distribution of the former two species, P. kinositae and $P$. retorta, may have expanded to northern Japan through the restored East Korean Warm Current after the LGM (Fig. 3B). Interestingly, Pyropia sp. P10 (AB366146), considered a sibling species of $P$. retorta currently, has not been found on the east coast of Korea to date in spite of our close attention in collection. The distributional differences between P. retorta and Pyropia sp. P10, although 


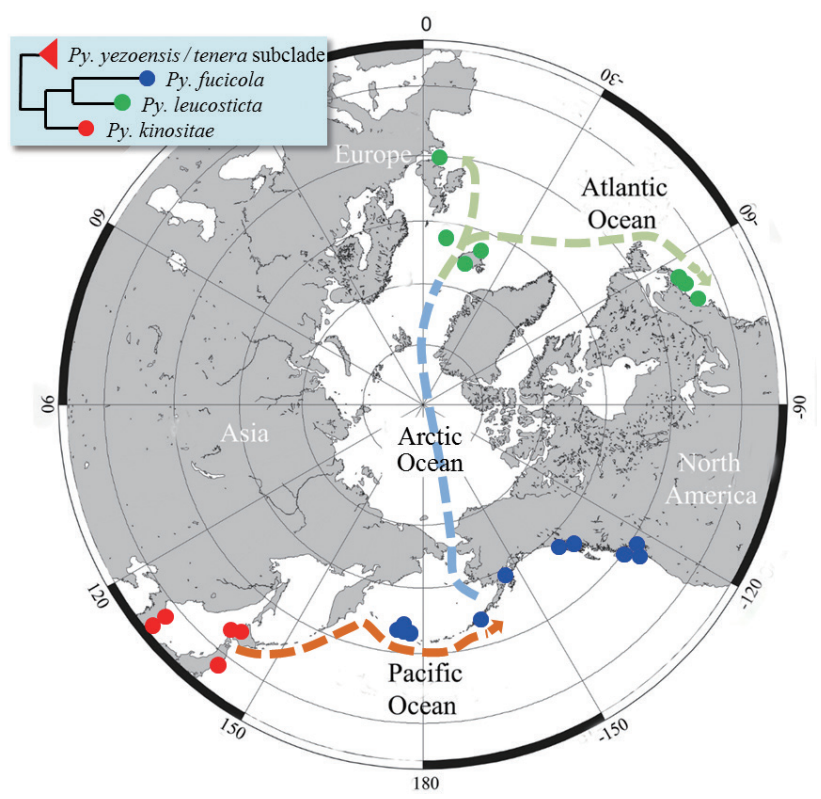

Fig. 4. A scenario of historical biogeography of the Pyropia kinositae / P. leucosticta / P. fucicola clade based on the species phylogeny and distributional data of GenBank sequences.

currently sympatric in the northeast coast of Japan (Niwa et al. 2014), suggests that they may be a vicariant pair, possibly separated relicts from different refuges; one located on the east coast of Korea (P. retorta) and the other perhaps placed on the east coast of central Japan (Pyropia sp. P10) during the LGM. The scenario of postglacial dispersal from different refuges, however, should be reconfirmed with further phylogeographic research based on more rapid evolutionary genetic markers than $r b c \mathrm{~L}$.

Eight native species of Pyropia occur on the east coast of Korea: 1) P. kinositae; 2) P. koreana (M. S. Hwang \& I. K. Lee) M. S. Hwang, H. G. Choi, Y. S. Oh \& I. K. Lee; 3) $P$. moriensis (Ohmi) N. Kikuchi \& M. Miyata; 4) P. retorta; 5) P. onoi (Ueda) N. Kikuchi \& M. Miyata; 6) P. pseudolinearis (Ueda) N. Kikuchi, M. Miyata, M. S. Hwang \& H. G. Choi; 7) Porphyra akasakae Miura; and 8) Po. irregularis Fukuhara (Kim and Kim 2011, This study). These species have only been reported in northern Japanese waters (Hokkaido, northeastern Honshu) or the east coast of Korea and the west coast of Japan, but not along the south coast of Korea (except $P$. kinositae in this study). The distribution pattern of these eight species suggests that the East Sea (= Japan Sea) seems to have played a major role as refugia during the LGM.

It has long been recognized that there are two kinds of endemic species: neo-endemics-recently diverged species that are endemic because of lack of dispersal / migration out of their ancestral area; and paleo-endemics-old species that were perhaps more widespread in the past and are now restricted to a local region (Nekola 1999, Mishler et al. 2014). It could be a reliable method to peer into the hypothesis of biogeography through the species phylogenetic tree combined with distributional information, and also to detect the differentiation between areas with clusters of new emerging species (neoendemics) and areas with clusters of unique, but disappearing, species (paleo-endemics) that often occur in restricted areas of their refuges or origin (Mishler et al. 2014). Following the concept of endemics, $P$. retorta is a neo-endemic, whereas $P$. kinositae is a paleo-endemic species in our phylogenetic tree (Fig. 1) and as shown in the scenario of the historical biogeography of the $P$. kinositae lineage (Fig. 4).

Interestingly, an accelerated rate of evolution was found in subclades IV, VIII, and IX, which have remarkably long branches leading to terminal species. Generally, an accelerated rate of evolution may be caused by an increased fixation rate of new mutations, which is affected by natural selection (purifying), population size, and rate of cladogenesis (Mindell and Thacker 1996). The relatively milder environments in the Southern hemisphere and warm temperate to tropical Oceans compared to those of the northern Pacific during the glacial epoch probably led to the acceleration, which may have been caused by weak selection pressures and few cladogenesis or fragmentation of populations. On the other hand, the rapid cladogenesis of Pyropia that was recognized on both sides of the North Pacific may occur because of TransPacific dispersal and repeated fragmentation of populations in response to climatic cooling during the Cenozoic (Briggs 2003). The Trans-Pacific and / or Trans-Arctic dispersal followed by long-term isolation (and bottlenecks?) was observed in the $P$. fucicola / P. leucosticta / $P$. kinositae lineage as shown in the scenario of the historical biogeography of the Pyropia kinositae lineage (Fig. 4), and in the P. kurogii / P. njordii and P. peggiconvensis I Porphyra sp. SCL-2008-2 lineage (Fig. 1). Generally, the subtropical to warm temperate species of Pyropia, e.g., $P$. acanthophora show much more genetic diversity including $20 \mathrm{rbcL}$ haplotypes (Dumilag and Aguinaldo 2017). However, $P$. kinositae and P. retorta have low genetic diversity, with only two $r b c \mathrm{~L}$ haplotypes detected. The low genetic diversity of these two species may be the result of a severe bottleneck effect (purifying) during the glacial epoch in the Cenozoic or recent population expansion.

Much attention is needed to explain the hypothesis of biogeography of the well resolved subclade I, which 
is composed of 13 species including $P$. yezoensis, an economically important species for nori cultivation in Korea and Japan (Fig. 1). It is thought that members of this subclade have complex dispersal histories, including TransPacific, Trans-Artic, and Trans-equatorial (anti-tropical) distributions. This subclade is a monophyletic lineage with a very strongly supported branching pattern in the $r b c \mathrm{~L}$ phylogeny (Kucera and Saunders 2012, This study) and SSU-rDNA + rbcL concatenated data (Sutherland et al. 2011, Sánchez et al. 2014). The long ancestral branch of this genetic lineage likely reflects an earlier separation with long independent history of cladogenesis from the sister subclades II and III. Overall, a complex dispersal hypothesis, including Trans-Pacific, Trans-Arctic, and Trans-equatorial can be safely stated to explain the cladogenesis of this genetic lineage. The hypothesis of Trans-Pacific and / or Trans-Arctic migration has been well-documented in many marine biota, especially focusing on the North Pacific-North Atlantic connections during the Pleistocene based on molecular data (Lindstrom 2001, Nikula et al. 2007, Coyer et al. 2011). Transequatorial dispersal based on molecular data has been discussed in the case of marine algae (Hommersand and Fredericq 2003), for some marine animals (Williams et al. 2003, Mabuchi et al. 2004, Gérard et al. 2008, Naughton et al. 2014) and terrestrial plants (Nakamura et al. 2012).

\section{ACKNOWLEDGEMENTS}

We thank Dr. Hwang Il-Gi for field collections. This study was supported by grants from National Institute of Biological Resources (NIBR), funded by the Ministry of Environment (MOE) of the Republic of Korea to H. -S. Kim (NIBR201401204), and the Basic Research Program of the Korea Polar Research Institute Project to S. -M. Kim and H. -G. Choi (PE18150).

\section{SUPPLEMENTARY MATERIAL}

Supplementary Table 1. GenBank accession numbers of $r b c \mathrm{~L}$ sequences used in the phylogenetic analysis (http://e-algae.org).

Supplementary Fig. S1. Pyropia onoi. (A) A dried herbarium specimens (KU407). (B) Vegetative cells in the surface view of the middle part of thallus, showing more or less regular arrangement. (C) Vegetative cells in the cross-section view of the middle part of thallus. (D) Marginal portion of the lower part of thallus. (E) Surface view of spermatangial sori. Scale bars represent: A, $1 \mathrm{~cm}$; B, C \& E, $10 \mu \mathrm{m} ; \mathrm{D}, 100 \mu \mathrm{m}$ (http://e-algae.org).

Supplementary Fig. S2. Pyropia moriensis. (A) A dried herbarium specimens (KU408). (B) Marginal portion of the lower part of thallus. (C \& D) Vegetative cells in the surface view of the middle part of thallus. (E) Surface view of zygotosporangial sori. (F) Surface view of spermatangial sori. (G) Vegetative cells in the cross-section of the middle part. Scale bars represent: A, $5 \mathrm{~cm}$; B \& G, 20 $\mu \mathrm{m}$; C-F, $10 \mu \mathrm{m}$ (http://e-algae.org).

Supplementary Fig. S3. Pyropia kinositae. (A \& B) Herbarium specimens (IK153, IK327). (C) Vegetative cells and smooth margin in the surface view of the middle part of frond. (D) Vegetative cells in the cross section of the middle part. (E) Surface view of sori of spermatangia. (F) Surface view of sori of zygotosporangia. (G) Carpogonia with slight protruded prototrichogynes in the cross section. (H) Development of zygotosporangia in the cross section. Scale bars represent: A \& B, $5 \mathrm{~cm}$; C-H, $20 \mu \mathrm{m}$ (http://e-algae.org).

\section{REFERENCES}

Agardh, C. A. 1824. Systema Algarum. Literis Berlingiana, Lund, $312 \mathrm{pp}$.

Anisimova, M. \& Gascuel, O. 2006. Approximate likelihoodratio test for branches: a fast, accurate, and powerful alternative. Syst. Boil. 55:539-552.

Bárbara, I., Choi, H. -G., Secilla, A., Díaz-Tapia, P., Gorostiaga, J. M., Seo, T. -K., Jung, M. -Y. \& Berecibar, E. 2013. Lampisiphonia iberica gen. et sp. nov. (Ceramiales, Rhodophyta) based on morphology and molecular evidence. Phycologia 52:137-155.

Broom, J. E. S., Nelson, W. A., Farr, T. J., Phillips, L. E. \& Clayton, M. 2010. Relationships of the Porphyra (Bangiales, Rhodophyta) flora of the Falkland Islands: a molecular survey using rbcL and nSSU sequence data. Aust. Syst. Bot. 23:27-37.

Butterfield, N. I. 2000. Bangiomorpha pubescens n. gen., n. sp.: implications for the evolution of sex, multicellularity, and the Mesoproterozoic/Neoproterozoic radiation of eukaryotes. Paleobiology 26:386-404.

Coyer, J. A., Hoarau, G., Van Schaik, J., Luijckx, P. \& Olsen, J. L. 2011. Trans-Pacific and trans-Arctic pathways of the intertidal macroalga Fucus distichus L. reveal multiple glacial refugia and colonizations from the North Pacific to the North Atlantic. J. Biogeogr. 38:756-771.

Darriba, D., Taboada, G. L., Doallo, R. \& Posada, D. 2012. jModelTest 2: more models, new heuristics and parallel 
computing. Nat. Methods 9:772.

Dumilag, R. V. \& Aguinaldo, Z. -Z. A. 2017. Genetic differentiation and distribution of Pyropia acanthophora (Bangiales, Rhodophyta) in the Philippines. Eur. J. Phycol. 52: 104-115.

Dumilag, R. V. \& Monotilla, W. D. 2017. Molecular diversity and biogeography of Philippine foliose Bangiales (Rhodophyta). J. Appl. Phycol. Online version (doi. org/10.1007/s10811-017-1201-8).

Engler, A. 1892. Syllabus der Vorlesungen Über Specielle und Medicinisch-Pharmaceutische Botanik. Eine Uebersicht Über das Ganze Pflanzensystem mit Berücksichtigung der Medicinal- und Nutzpflanzen. Grosse Ausgabe, Berlin, 184 pp.

Freshwater, D. W. \& Rueness, J. 1994. Phylogenetic relationships of some European Gelidium (Gelidiales, Rhodophyta) species based upon $r b c \mathrm{~L}$ nucleotide sequences analysis. Phycologia 33:187-194.

Fukuhara, E. 1968. Studies on the taxonomy and ecology of Porphyra of Hokkaido and its adjacent waters. Bull. Hokkaido Reg. Fish. Res. Lab. 34:40-99.

Gérard, K., Bierne, N., Borsa, P., Chenuil, A. \& Féral, J. -P. 2008. Pleistocene separation of mitochondrial lineages of Mytilus spp. mussels from Northern and Southern Hemispheres and strong genetic differentiation among southern populations. Mol. Phylogenet. Evol. 49:84-91.

Guillemin, M. -L., Contreras-Porcia, L., Ramírez, M. E., Macaya, E. C., Contador, C. B., Woods, H., Wyatt, C. \& Brodie, J. 2016. The bladed Bangiales (Rhodophyta) of the South Eastern Pacific: molecular species delimitation reveals extensive diversity. Mol. Phylogenet. Evol. 94:814-826.

Guindon, S., Dufayard, J. F., Lefort, V., Anisimova, M., Hordijk, W. \& Gascuel, O. 2010. New algorithms and methods to estimate maximum-likelihood phylogenies: assessing the performance of PhyML 3.0. Syst. Boil. 59:307-321.

Guiry, M. D. \& Guiry, G. M. 2017. AlgaeBase. World-wide electronic publication, National University of Ireland, Galway. Available from: http://www.algaebase.org. Accessed Feb 15, 2017.

Hall, T. A. 1999. BioEdit: a user-friendly biological sequence alignment editor and analysis program for Windows 95/98/NT. Nucleic Acids Symp. Ser. 41:95-98.

Harden, L. K., Morales, K. M. \& Hughey, J. R. 2015. Identification of a new marine algal species Pyropia nitida sp. nov. (Bangiales: Rhodophyta) from Monterey, California. Mitochondrial DNA A DNA Mapp. Seq. Anal. 27:3058-3062.

Hommersand, M. H. \& Fredericq, S. 2003. Biogeography of the marine red algae of the South Africa west coast: a molecular approach. In Chapman, A. R. O., Anderson,
R. J., Vreeland, V. J. \& Davison, I. R. (Eds.) Proc. 17th Int. Seaweed Symp., Oxford University Press, Oxford, pp. 325-336.

Huelsenbeck, J. P. \& Ronquist, F. 2001. MRBAYES: Bayesian inference of phylogenetic trees. Bioinformatics 17:754755.

Hwang, M. S. \& Lee, I. K. 2001. Taxonomy of the genus Porphyra (Bangiales, Rhodophyta) from Korea. Algae 16:233-273.

Kim, H. -S., Boo, S. M., Lee, I. K. \& Sohn, C. H. 2013. National list of species of Korea Marine algae. National Institute of Biological Resources, Incheon, $336 \mathrm{pp}$.

Kim, H. -S. \& Kim, S. -M. 2011. Algal flora of Korea. Vol. 4, Npo. 1. Rhodophyta: Stylonematophyceae, Compsopogonophyceae, Bangiophyceae. Primitive red algae. National Institute of Biological Resources, Incheon, $138 \mathrm{pp}$.

Kim, S. -M. 2005. Morphology and molecular phylogeny of Porphyra yezoensis Ueda and its related species in Korea. M.S. thesis, Gangneung National University, Wonju, $61 \mathrm{pp}$.

Kim, Y., Choi, S. -J. \& Choi, C. 2017. An efficient PCR-RFLP method from the rapid identification of Korean Pyropia species. Molecules 22:E2182.

Korean Hydrographic and Oceanographic Agency. Quasireal-time ocean current using satellite altimetry data. Available from: http://www.khoa.go.kr/koofs/kor/seawf/sea_wflow.do?menuNo. Accessed Feb 15, 2017.

Kucera, H. \& Saunders, G. W. 2012. A survey of Bangiales (Rhodophyta) based on multiple molecular markers reveals cryptic diversity. J. Phycol. 48:869-882.

Kunimoto, M., Kito, H., Yamamoto, Y., Cheney, D. P., Kaminishi, Y. \& Mizukami, Y. 1999. Discrimination of Porphyra species based on small subunit ribosomal RNA gene sequence. J. Appl. Phycol. 11:203-209.

Lindstrom, S. C. 2001. The Bering Strait connection: dispersal and speciation in boreal macroalgae. J. Biogeogr. 28:243-251.

Lindstrom, S. C. 2008. Cryptic diversity, biogeography and genetic variation in Northeast Pacific species of Porphyra sensu lato (Bangiales, Rhodophyta). J. Appl. Phycol. 20:951-962.

Lindstrom, S. C. \& Fredericq, S. 2003. rbcL gene sequences reveal relationships among north-east Pacific species of Porphyra (Bangiales, Rhodophyta) and a new species, $P$. aestivalis. Phycol. Res. 51:211-224.

Lindstrom, S. C., Hughey, J. R. \& Aguilar Rosas, L. E. $2015 a$. Four new species of Pyropia (Bangiales, Rhodophyta) from the west coast of North America: the Pyropia lanceolata species complex updated. PhytoKeys 52:1-22.

Lindstrom, S. C., Lindeberg, M. R. \& Guthrie, D. A. $2015 b$. 
Marine macroalgae of the Aleutian Islands: I. Bangiales. Algae 30:247-263.

López-Vivas, J. M., Muñiz-Salazar, R., Riosmena-Rodríguez, R., Pacheco-Ruíz, I. \& Yarish, C. 2015. Endemic Pyropia species (Bangiales, Rhodophyta) from the Gulf of California, Mexico. J. Appl. Phycol. 27:1029-1041.

Lyngbye, H. C. 1819. Tentamen Hydrophytologiae Danicae Continens Omnia Hydrophyta Cryptogama Daniae, Holsatiae, Faeroae, Islandiae, Groenlandiae Hucusque Cognita, Systematice Disposita, Descripta et Iconibus Illustrata, Adjectis Simul Speciebus Norvegicis. Typis Schultzianis, in commissis Librariae Gyldendaliae, Copenhagen, $248 \mathrm{pp}$.

Mabuchi, K., Nakabo, T. \& Nishida, M. 2004. Molecular phylogeny of the antitropical genus Pseudolabrus (Perciformes: Labridae): evidence for a Southern Hemisphere origin. Mol. Phylogent. Evol. 32:375-382.

Mateo-Cid, L. E., Mendoza-Gonzalez, A. C., Díaz-Larrea, J., Sentíes, A., Pedroche, F. F. \& Sánchez Heredia, J. D. 2012. A new species of Pyropia (Rhodophyta, Bangiaceae), from the Pacific coast of Mexico, based on morphological and molecular evidence. Phytotaxa 54:1-12.

Milstein, D., Medeiros, A. S., Oliveira, E. C. \& Oliveira, M. C. 2012. Will a DNA barcoding approach be useful to identify Porphyra species (Bangiales, Rhodophyta)? A case study with Brazilian taxa. J. Appl. Phycol. 24:837-845.

Milstein, D., Medeiros, A. S., Oliveira, E. C. \& Oliveira, M. C. 2015. Native or introduced? A re-evaluation of Pyropia species (Bangiales, Rhodophyta) from Brazil based on molecular analyses. Eur. J. Phycol. 50:37-45.

Mindell, D. P. \& Thacker, C. E. 1996. Rates of molecular evolution: phylogenetic issues and applications Annu. Rev. Ecol. Syst. 27:279-303.

Mishler, B. D., Knerr, N., González-Orozco, C. E., Thornhill, A. H., Laffan, S. W. \& Miller, J. T. 2014. Phylogenetic measures of biodiversity and neo- and paleo-endemism in Australian Acacia. Nat. Commun. 5:4473.

Mols-Mortensen, A., Neefus, C. D., Nielsen, R., Gunnarsson, K., Egilsdóttir, S., Pedersen, P. M. \& Brodie, J. 2012. New insights into the biodiversity and generic relationships of foliose Bangiales (Rhodophyta) in Iceland and the Faroe Islands. Eur. J. Phycol. 47:146-159.

Mols-Mortensen, A., Neefus, C. D., Pedersen, P. M. \& Brodie, J. 2014. Diversity and distribution of foliose Bangiales (Rhodophyta) in West Greenland: a link between the North Atlantic and North Pacific. Eur. J. Phycol. 49:1-10.

Nakamura, K., Denda, T., Kokubugata, G., Forster, P. I., Wilson, G., Peng, C. -I. \& Yokota, M. 2012. Molecular phylogeography reveals an antitropical distribution and local diversification of Solenogyne (Asteraceae) in the
Ryukyu Archipelago of Japan and Australia. Biol. J. Lin. Soc. 105:197-217.

Naughton, K. M., O’Hara, T. D., Appleton, B. \& Cisternas, P. A. 2014. Antitropical distributions and species delimitation in a group of ophiocomid brittle stars (Echinodermata, Ophiuroidea: Ophiocomidae). Mol. Phylogenet. Evol. 78:232-244.

Nekola, J. C. 1999. Paleorefugia and neorefugia: the influence of colonization history on community pattern and process. Ecology 80:2459-2473.

Nelson, W. A. 2013. Pyropia plicata sp. nov. (Bangiales, Rhodophyta): naming a common intertidal alga from New Zealand. PhytoKeys 21:17-28.

Nelson, W. A. \& D'Archino, R. 2014. Three new macroalgae from the Three Kings Islands New Zealand including the first southern Pacific Ocean record of the Furcellariaceae (Rhodophyta). Phycologia 53:602-613.

Nikula, R., Strelkov, P. \&Väinölä, R. 2007. Diversity and transarctic invasion history of mitochondrial lineages in the North Atlantic Macoma balthica complex (Bivalvia: Tellinidae). Evolution 61:928-941.

Niwa, K., Iida, S., Kato, A., Kawai, H., Kikuchi, N., Kobiyama, A. \& Aruga, Y. 2009. Genetic diversity and introgression in two cultivated species (Porphyra yezoensis and Porphyra tenera) and closely related wild species or Porphyra (Bangiales, Rhodophyta). J. Phycol. 45:493-502.

Niwa, K., Kikuchi, N., Hwang, M. S., Choi, H. -G. \& Aruga, Y. 2014. Cryptic species in the Pyropia yezoensis complex (Bangiales, Rhodophyta): sympatric occurrence of two cryptic species even on same rocks. Phycol. Res. 62:3643.

Niwa, K. \& Kobiyama, A. 2014. Speciation in the marine crop Pyropia yezoensis (Bangiales, Rhodophyta). J. Phycol. 50:897-900.

Niwa, K. \& Sakamoto, T. 2010. Allopolyploidy in natural and cultivated populations of Porphyra (Bangiales, Rhodophta). J. Phycol. 46:1097-1105.

Notoya, M. \& Miyashita, A. 1999. Life history, in culture, of the obligate epiphyte Porphyra moriensis (Bangiales, Rhodophyta). Hydrobiologia 398/399:121-125.

Ohmi, H. 1954. New species of Porphyra, epiphytic on Chorda filum from Hokkaido. Bull. Fac. Fish. Hokkaido Univ. 5:231-239.

Ramírez, M. -E., Contreras-Porcia, L., Guillemin, M. -L., Brodie, J., Valdivia, C., Flores-Molina, M. R., Núñez, A., Bulboa Contador, C. \& Lovazzano, C. 2014. Pyropia orbicularis sp. nov. (Rhodophyta, Bangiaceae) based on a population previously known as Porphyra columbina from the central coast of Chile. Phytotaxa 158:133-153.

Sánchez, N., Vergés, A., Peteiro, C., Sutherland, J. E. \& Brodie, 
J. 2014. Diversity of bladed Bangiales (Rhodophyta) in western Mediterranean: recognition of the genus Themis and description of T. ballesterosii sp. nov., T. iberica sp. nov., and Pyropia parva sp. nov. J. Phycol. 50:908-929.

Sánchez, N., Vergés, A., Peteiro, C., Sutherland, J. E. \& Brodie, J. 2015. Diversity of bladed Bangiales (Rhodophyta) in western Mediterranean: recognition of the genus Themis and description of $T$. ballesterosii sp. nov., T. iberica sp. nov., and Pyropia parva sp. nov. (Corrigendum). J. Phycol. 51:401.

Saunders, G. W. \& Kraft, G. T. 1994. Small-subunit rRNA gene sequences from representatives of selected families of the Gigartinales and Rhodymeniales (Rhodophyta). 1. Evidence for the Plocamiales ord.nov. Can. J. Bot. 72:1250-1263

Smith, D. R., Hua, J., Lee, R. W. \& Keeling, P. J. 2012. Relative rates of evolution among the three genetic compartments of the red alga Porphyra differ from those of green plants and do not correlate with genome architecture. Mol. Phylogenet. Evol. 65:339-344.

Stiller, J. W. \& Waaland, J. R. 1993. Molecular analysis reveals cryptic diversity in Porphyra (Rhodophyta). J. Phycol. 29:506-517.

Sutherland, J. E., Lindstrom, S. C., Nelson, W. A., Brodie, J., Lynch, M. D. J., Hwang, M. S., Choi, H. -G., Miyata, M., Kikuchi, N., Oliveira, M. C., Farr, T., Neefus, C., MolsMortensen, A., Milstein, D. \& Müller, K. M. 2011. A new look at an ancient order: generic revision of the Bangia- les (Rhodophyta). J. Phycol. 47:1131-1151.

Tamura, K., Peterson, D., Peterson, N., Stecher, G., Nei, M. \& Kumar, S. 2011. MEGA5: molecular evolutionary genetics analysis using maximum likelihood, evolutionary distance, and maximum parsimony methods. Mol. Boil. Evol. 28:2731-2739.

Tanaka, T. 1952. The systematic study of the Japanese Protoflorideae. Mem. Fac. Fish. Kagoshima Univ. 2:1-92.

Teasdale, B. W., West, A., Klein, A. S. \& Mathieson, A. C. 2009. Distribution and evolution of variable group-I introns in the small ribosomal subunit of North Atlantic Porphyra (Bangiales, Rhodophyta). Eur. J. Phycol. 44:171-182.

Ueda, S. 1932. Systematic study of the genus Porphyra in Japan. Suiko-Kenkyu-Kokoku 28:1-45.

Verbruggen, H. 2014. Morphological complexity, plasticity, and species diagnosability in the application of old species names in DNA-based taxonomics. J. Phycol. 50:2631.

Williams, S. T., Reid, D. G. \& Littlewood, D. T. J. 2003. A molecular phylogeny of the Littorininae (Gastropoda: Littorinidae): unequal evolutionary rates, morphological parallelism, and biogeography of the Southern Ocean. Mol. Phylogenet. Evol. 28:60-86.

Xie, Z. -Y., Lin, S. -M., Liu, L. -C., Ang, P. O. Jr. \& Shyu, J. -F. 2015. Genetic diversity and taxonomy of foliose Bangiales (Rhodophyta) from Taiwan based on $r b c \mathrm{~L}$ and cox 1 sequences. Bot. Mar. 58:189-202. 